\title{
Lack of assembly of mitochondrial DNA-encoded subunits of respiratory NADH dehydrogenase and loss of enzyme activity in a human cell mutant lacking the mitochondrial ND4 gene product
}

\section{Götz Hofhaus and Giuseppe Attardi}

Division of Biology, California Institute of Technology, Pasadena, CA 91125, USA

Communicated by G.Schatz

In most eukaryotic cells, the respiratory chain NADH dehydrogenase (Complex I) is a multimeric enzyme under dual (nuclear and mitochondrial) genetic control. Several genes encoding subunits of this enzyme have been identified in the mitochondrial genome from various organisms, but the functions of these subunits are in most part unknown. We describe here a human cell line in which the enzyme lacks the mtDNA-encoded subunit ND4 due to a frameshift mutation in the gene. In this cell line, the other mtDNA-encoded subunits fail to assemble, while at least some of the nuclear-encoded subunits involved in the redox reactions appear to be assembled normally. In fact, while there is a complete loss of NADH: $\mathbf{Q}_{1}$ oxidoreductase activity, the NADH:Fe(CN) 6 oxidoreductase activity is normal. These observations provide the first clear evidence that the ND4 gene product is essential for Complex I activity and give some insights into the function and the structural relationship of this polypeptide to the rest of the enzyme. They are also significant for understanding the pathogenetic mechanism of the ND4 gene mutation associated with Leber's hereditary optic neuropathy.

Key words: Complex I/cybrid/frameshift mutation/mtDNAless $\left(\varrho^{\circ}\right)$ cell/polarography

\section{Introduction}

The mitochondrial NADH dehydrogenase (Complex I) (Weiss et al., 1991), the largest enzyme complex of the respiratory chain, consists of $\sim 40$ subunits in the mammalian enzyme (Walker, 1992) and $\sim 30$ in the Neurospora crassa enzyme (Weiss et al., 1991), of which seven are encoded in mitochondrial DNA (mtDNA) (Chomyn et al., 1985, 1986; Weiss et al., 1991). In Neurospora, the enzyme has been shown to have an overall L-shaped structure (Hofhaus et al., 1991), and it is likely that this model applies also to the mammalian enzyme. One arm of the ' $\mathrm{L}$ ' is buried in the inner mitochondrial membrane and contains all mtDNA-encoded subunits, while the other arm protrudes into the matrix and contains most of the prosthetic groups that are involved in the redox reactions (Hofhaus et al., 1991). With the exception of the ND1 gene product, nothing is known about the functions of the mtDNA-encoded subunits, despite the knowledge of their primary structure (Anderson et al., 1981). The ND1 subunit is known to bind rotenone, a specific inhibitor of Complex I (Earley et al. , 1987), and to interact with ubiquinone (Friedrich et al., 1990). Furthermore, it has been reported that the $N D 1$ gene product binds $N, N^{\prime}$-dicyclohexyl- carbodiimide (DCCD) (Yagi and Hatefi, 1988), suggesting that it may be involved in proton translocation.

Further progress in our understanding of the functional role of the mtDNA-encoded subunits of Complex I will depend on the availability of mutants. In this context, the discovery of natural mtDNA mutations affecting the ND4 or ND1 subunit of NADH dehydrogenase, with resulting Complex I deficiency, in patients affected by Leber's hereditary optic neuropathy (Wallace, 1992) has opened one way for investigating the mutation-induced structural and functional changes in these subunits either directly in the patients' cells or after transfer of the patients' mitochondria into human mtDNA-less $\left(\varrho^{\circ}\right)$ cells (King and Attardi, 1989; Chomyn et al., 1991). A complementary approach would involve the isolation of artificial mtDNA mutants affected in subunits of NADH dehydrogenase from human cell lines. We describe here the first example of in vitro isolation of this class of mutants. In the course of investigations on rotenone-resistant mutants of the human cell line $\mathrm{VA}_{2} \mathrm{~B}$ (Mitchell et al., 1975), we found one mutant (C4) that exhibited a complete loss of NADH-dependent respiration. The respiration defect could be transferred to a human $e^{\circ}$ cell line with the mitochondria from the $\mathrm{C} 4$ mutant. Protein synthesis, immunoprecipitation and DNA sequencing experiments indicated that the defect resulted from the absence of the mtDNA-encoded subunit ND4, due to a frameshift mutation in the corresponding gene.

\section{Results and Discussion}

\section{Isolation of a human cell mutant with a defect in NADH-dependent respiration}

Among several $\mathrm{VA}_{2} \mathrm{~B}$ clones capable of growing in the presence of $1 \mu \mathrm{M}$ rotenone, one (C4) was analyzed in detail. Surprisingly, the rotenone-sensitive $\mathrm{O}_{2}$ consumption of this mutant, measured in intact cells (King and Attardi, 1989), was found to be much lower than that of $\mathrm{VA}_{2} \mathrm{~B}$ cells $(<0.5$ $\mathrm{fmol} / \mathrm{min} /$ cell compared with $2.5 \mathrm{fmol} / \mathrm{min} /$ cell). In order to pinpoint the block in the respiratory chain of $\mathrm{C} 4$ cells, an approach involving digitonin-permeabilized cells and different substrates and inhibitors (Granger and Lehninger, 1982) was used. In this approach, with malate and glutamate as substrates, the corresponding dehydrogenases generate $\mathrm{NADH}$, which is oxidized in three discrete steps by the NADH:ubiquinone oxidoreductase or NADH dehydrogenase (Complex I), the ubiquinol:cytochrome $c$ oxidoreductase (Complex III) and the cytochrome $c$ oxidase (Complex IV). The overall reaction is measured by the $\mathrm{O}_{2}$ consumption in the terminal step:

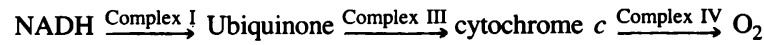

Using succinate and glycerol-3-phosphate as substrates, the corresponding dehydrogenases cause a direct reduction of ubiquinone, bypassing Complex I. Similarly, using $N, N, N^{\prime} N^{\prime}$-tetramethyl-p-phenylenediamine (TMPD) and 
ascorbate, cytochrome $c$ is reduced and the activity of Complex IV alone is measured. A comparison of the slopes obtained with different substrates allows the determination of the rate limiting step in the respiratory chain. It appears from Figure 1 that the lack of respiration in the mutant $\mathrm{C} 4$ is due to a defect in NADH-dependent respiration, and therefore, presumably, in Complex I. In fact, bypassing Complex $I$ in the mutant with either succinate + glycerol-3-phosphate or TMPD + ascorbate results in a much faster $\mathrm{O}_{2}$ consumption. Therefore, a defect in Complex III or Complex IV cannot account for the block in respiration with NADH-linked substrates. Furthermore, the absolute rates of $\mathrm{O}_{2}$ consumption with succinate + glycerol-3-phosphate or TMPD + ascorbate in the mutant are comparable with those in $\mathrm{VA}_{2} \mathrm{~B}$ cells, suggesting that the terminal part of the respiratory chain is functionally normal in the mutant.

\section{The Complex I defect is transferred to a $\varrho^{\circ}$ cell line with the mitochondria from the C4 mutant}

The defect in NADH-dependent respiration in $\mathrm{C} 4$ could be due to a mutation in either a nuclear gene or a mitochondrial gene for a subunit of Complex I. The mtDNA-less $\left(e^{\circ}\right)$ 143B.206 cell line (King and Attardi, 1989) offered a very convenient approach to distinguish between these two possibilities. Mitochondria from $\mathrm{C} 4$ mutant cells were transferred into $\varrho^{\circ}$ cells by fusion with cytoplasts (enucleated cells) derived from the C4 mutant cells (King and Attardi, 1989), thus producing the transformant cell line C4T, which contains the mtDNA of the mutant, but in a different nuclear background. As shown in Figure 2, the NADHdependent respiration defect was transferred with the mtDNA. By contrast, the transformant C4T was not able to grow in the presence of $1 \mu \mathrm{M}$ rotenone, a finding which suggested that a nuclear gene mutation was responsible for the rotenone resistance of the original C4 mutant. Therefore, the respiratory defect in $\mathrm{C} 4$ that was being investigated here, appeared to be due to a mutation unrelated to that producing the rotenone resistance. As will be reported elsewhere (G.Hofhaus and G.Attardi, in preparation), other $\mathrm{VA}_{2} \mathrm{~B}$

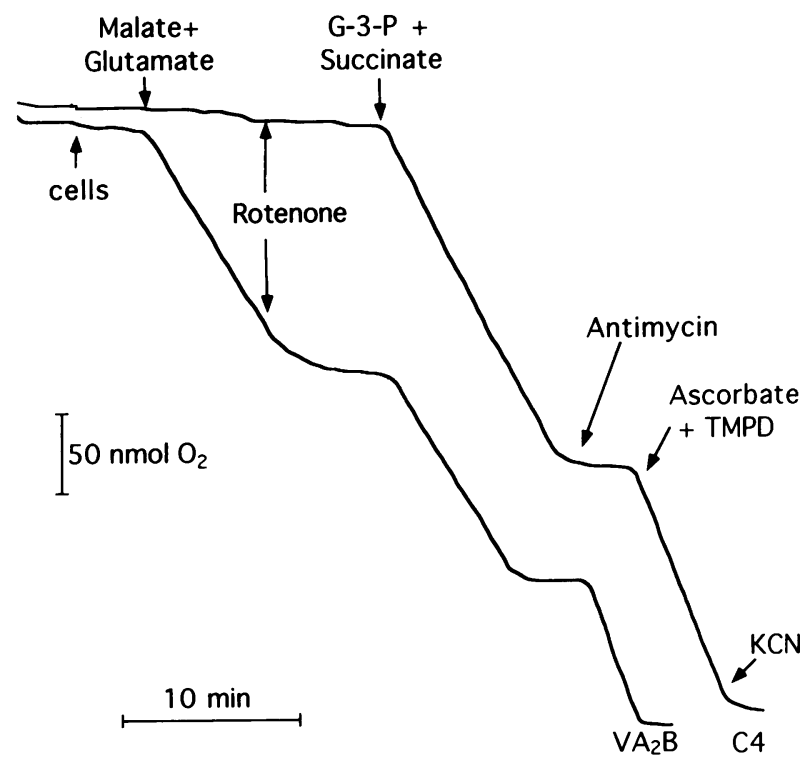

Fig. 1. $\mathrm{O}_{2}$ consumption by digitonin-permeabilized (Granger and Lehninger, 1982) $\mathrm{C} 4$ and $\mathrm{VA}_{2} \mathrm{~B}$ cells in the presence of different substrates and inhibitors. clones capable of growing in the presence of $1 \mu \mathrm{M}$ rotenone have recently been shown to exhibit a defect in NADHdependent respiration. As in the case of $\mathrm{C} 4$, this defect was transferred with the mtDNA into $\varrho^{\circ}$ cells, whereas the resistance to rotenone was not. A reasonable interpretation of these results is that, in the isolated $\mathrm{VA}_{2} \mathrm{~B}$ clones, which were resistant to $1 \mu \mathrm{M}$ rotenone due to a nuclear mutation affecting presumably the cell permeability to the drug, a secondary deleterious mutation in one of the mtDNAencoded subunits of Complex I made the clones defective in this enzyme activity also. Their growth became independent of respiration, and, therefore, resistant to any small amounts of rotenone leaking through the cell membrane. Also presented in Figure 2 is a control experiment showing that a transformant obtained by the transfer of mitochondria from HeLa cells into $\varrho^{\circ} 206$ cells had a normal NADH-dependent respiration.

The finding that the NADH-dependent respiration defect in the $\mathrm{C} 4$ cell line and its $\mathrm{C} 4 \mathrm{~T}$ derivative was associated with a mtDNA mutation tended to exclude the possibility that this defect involved the transport of the chosen substrates into the mitochondria or the activity of the corresponding dehydrogenases, rather than Complex I activity. In order to verify this conclusion, the $\mathrm{NADH}: \mathrm{Q}_{1}$ oxidoreductase activity was measured in partially purified mitochondrial membranes from the C4T cell line. Table I indeed shows that also this activity is completely absent in C4T, whereas the NADH: $\mathrm{Fe}(\mathrm{CN})_{6}$ oxidoreductase activity in this transformant is equal to that in $\mathrm{VA}_{2} \mathrm{~B}$ cells. The latter observation suggests that at least the nuclear-encoded portion of the enzyme that can be isolated as the flavoprotein fragment (Galante and Hatefi, 1979), and which is capable of carrying the $\mathrm{NADH}: \mathrm{Fe}(\mathrm{CN})_{6}$ oxidoreductase reaction, is assembled and associated with the membrane in the transformant.

\section{The C4T cell line exhibits a frameshift mutation in the mitochondrial ND4 gene}

In order to obtain some indications as to the possible site of the mtDNA mutation responsible for the Complex I defect

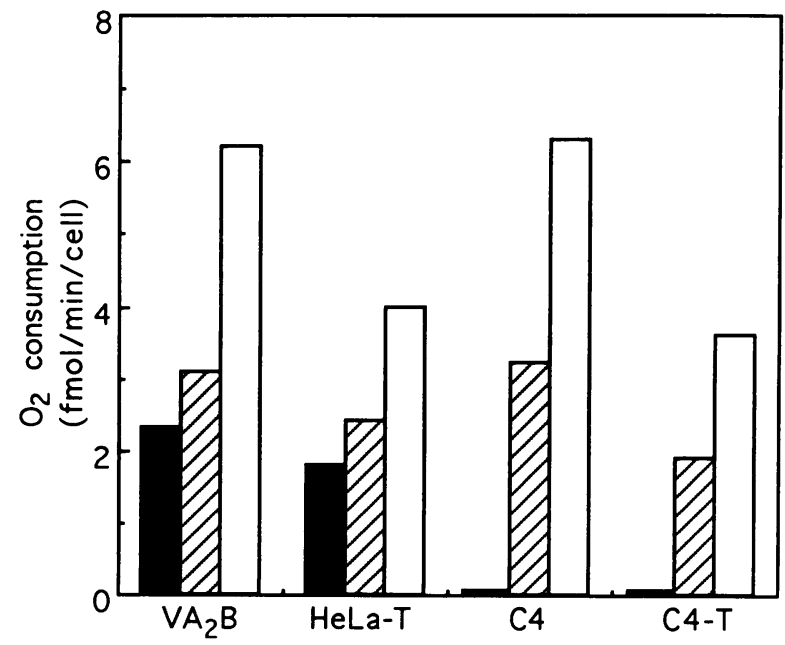

Fig. 2. Activities of the enzymes of the mitochondrial respiratory chain in the mutant clone $\mathrm{C} 4$ and the corresponding $\varrho^{\circ}$ cell transformant $\mathrm{C} 4 \mathrm{~T}, \mathrm{VA}_{2} \mathrm{~B}$ cells and a $\mathrm{HeLa} \varrho^{\circ}$ cell transformant. Using $\sim 9.5 \times 10^{6}$ digitonin-permeabilized cells, activities of the various components of the respiratory chain were determined as malate/glutamate (filled bars), glycero-3-phosphate/succinate (hatched bars) and ascorbate/TMPD (open bars) dependent respiration. 
in the $\mathrm{C} 4$ and $\mathrm{C} 4 \mathrm{~T}$ cell lines, the mitochondrial translation products of the $\mathrm{C} 4 \mathrm{~T}$ transformant and of the $\mathrm{VA}_{2} \mathrm{~B}$ cell line were specifically labeled for $2 \mathrm{~h}$ with $\left[{ }^{35} \mathrm{~S}\right]$ methionine in the presence of emetine, to block cytoplasmic protein synthesis (Chomyn et al., 1991). The electrophoretic patterns for C4T and $\mathrm{VA}_{2} \mathrm{~B}$ cells were found to be identical, except for the complete absence of the ND4 gene product in C4T. Also after short pulses (20 and $40 \mathrm{~min}$ ), there was no trace of the ND4 subunit in the electrophoretic pattern from this transformant; furthermore, there were no additional band(s) that could correspond to a truncated polypeptide(s).

The polymerase chain reaction (PCR)-amplified ND4 gene of the transformant was sequenced by the chain termination method (Sanger et al., 1977) and the sequence was compared with that of the $N D 4$ gene from the parental $\mathrm{VA}_{2} \mathrm{~B}$ cell line. An additional $\mathrm{C}$ residue was found in a row of six $\mathrm{C}$ residues at positions 10947-10952 in the Cambridge sequence (Anderson et al., 1981) (Figure 4). The insertion appeared to be homoplasmic or near-homoplasmic. Since the template utilized for PCR contained $>10^{7} \mathrm{mtDNA}$ molecules, the latter observation substantially excluded a PCR artefact, as confirmed by the sequencing of the product amplified in an independent reaction. The $\mathrm{C}$ insertion caused a frameshift that created a stop codon $\sim 150 \mathrm{bp}$ downstream. This frameshift mutation appeared, therefore, to be the cause of the premature termination of translation and of the disappearance of the ND4 gene product in the C4T transformant. The expected truncated polypeptide would have been 113 amino acids long and would have had a calculated molecular mass of $\sim 12.9 \mathrm{kDa}$. The absence of a polypeptide of this size among the mitochondrial translation products of C4T (Figure 3), even in the short $\left[{ }^{35} \mathrm{~S}\right]$ methionine pulse labeling experiments, points to its rapid degradation.

\section{The mtDNA-encoded subunits are not assembled into Complex I in the C4T cell line}

In order to investigate whether the assembly of the other mtDNA-encoded subunits of Complex I was affected in the C4T transformant, antibodies against the nuclear-encoded $49 \mathrm{kDa}$ subunit of the bovine enzyme, which is part of the matrix arm, were used to precipitate the whole human Complex I (Chomyn et al., 1986). In this experiment, only those mtDNA-encoded subunits that were assembled into the Complex I would be expected to be coprecipitated.

The mtDNA-encoded subunits of C4T cells and, as a control, those of $\mathrm{VA}_{2} \mathrm{~B}$ cells were labeled for $2 \mathrm{~h}$ with $\left.{ }^{35} \mathrm{~S}\right]$ methionine in the presence of cycloheximide (to inhibit cytoplasmic protein synthesis reversibly), and chased for $16 \mathrm{~h}$ in unlabeled medium in the absence of inhibitors, in

Table I. Measurement of the NADH: $\mathrm{Q}_{1}$ and $\mathrm{NADH}: \mathrm{Fe}(\mathrm{CN})_{6}$ oxidoreductase activities in mitochondrial membranes isolated from $\mathrm{C} 4 \mathrm{~T}$ and $\mathrm{VA}_{2} \mathrm{~B}$ cells

\begin{tabular}{lll}
\hline & $\mathrm{VA}_{2} \mathrm{~B}$ & $\mathrm{C} 4 \mathrm{~T}$ \\
\hline $\begin{array}{l}\mathrm{NADH}: \mathrm{Q}_{1} \\
(\mathrm{nmol} / \mathrm{min} / \mathrm{mg})\end{array}$ & $5.9 \pm 0.2$ & n.d. \\
$\begin{array}{l}\mathrm{NADH}: \mathrm{Fe}(\mathrm{CN})_{6} \\
(\mathrm{nmol} / \mathrm{min} / \mathrm{mg})\end{array}$ & $418 \pm 8$ & $411 \pm 16$ \\
\hline
\end{tabular}

The determinations were made in triplicate $\left(\mathrm{NADH}: \mathrm{Q}_{1}\right.$ oxidoreductase activity) or duplicate [NADH: $\mathrm{Fe}(\mathrm{CN})_{6}$ oxidoreductase activity]. n.d.: not detectable. order to allow their incorporation into Complex I. As shown in Figure 5, the electrophoretic pattern of an SDS mitochondrial lysate from $\mathrm{VA}_{2} \mathrm{~B}$ cells pulse-chased as described above revealed all the mitochondrial translation products, with a few extra bands in the high mol. wt region

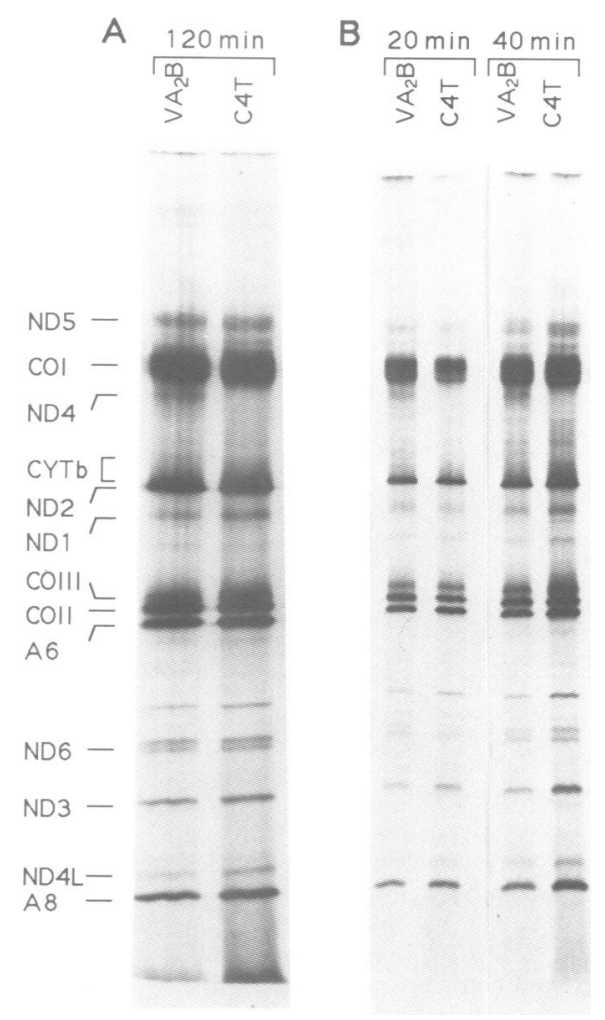

Fig. 3. Absence of the ND4 gene product from the newly synthesized mitochondrial translation products of C4T cells. Shown are the fluorograms, after polyacrylamide gradient gel electrophoresis, of samples of total cell lysates from $\mathrm{VA}_{2} \mathrm{~B}$ and $\mathrm{C} 4 \mathrm{~T}$ cells exposed to [35 S]methionine for the indicated times in the presence of $100 \mu \mathrm{g} / \mathrm{ml}$ emetine. Identification of the individual mitochondrial translation products was made according to Chomyn et al. (1991).

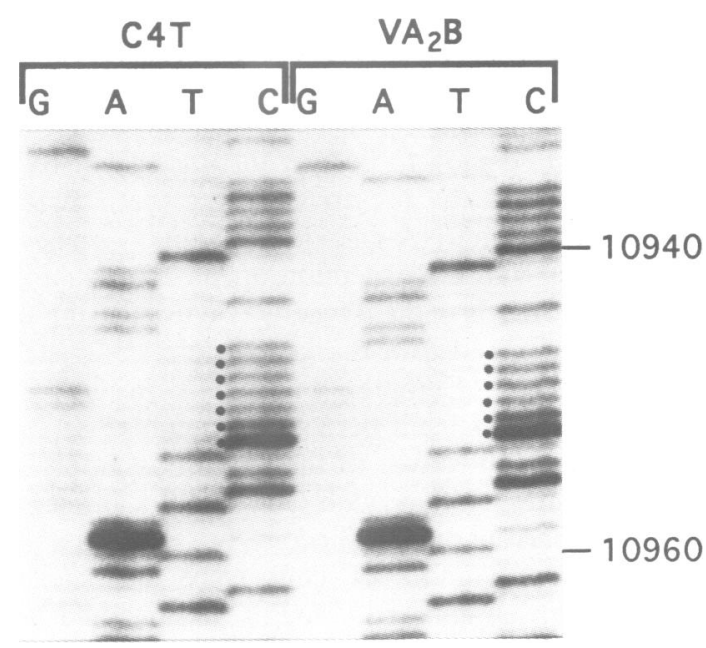

Fig. 4. Portion of the sequence of the ND4 gene from $\mathrm{VA}_{2} \mathrm{~B}$ and $\mathrm{C} 4 \mathrm{~T}$ cells (between positions 10932 and 10965 ), showing the insertion of a $\mathrm{C}$ residue in the C4T sequence. The single-stranded PCR product corresponding to the coding (light) strand was used as a template for sequencing by the chain termination method, and the sequence 


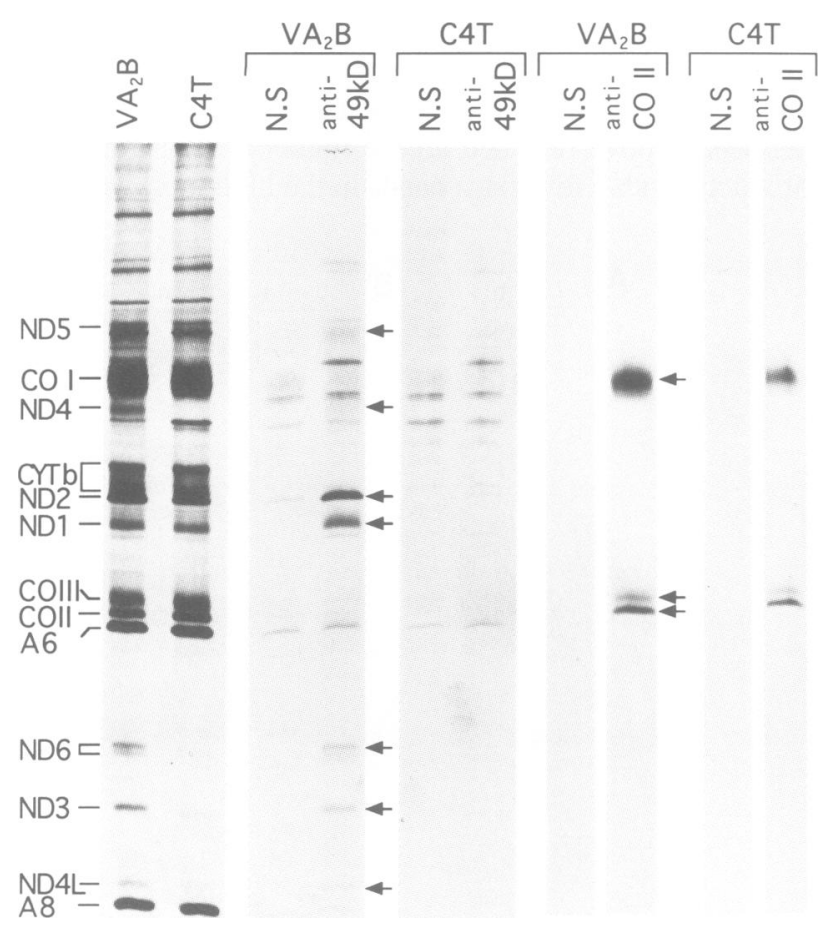

Fig. 5. Antibodies against the nuclear-encoded bovine $49 \mathrm{kDa}$ subunit precipitate the mtDNA-encoded subunits of Complex I from a $\mathrm{VA}_{2} \mathrm{~B}$ cell Triton X-100 mitochondrial lysate but not from a C4T cell mitochondrial lysate. Shown are fluorograms, after SDS-PAGE, of immunoprecipitates obtained by incubating samples of a $0.5 \%$ Triton $\mathrm{X}-100$ mitochondrial lysate from $\left[{ }^{35} \mathrm{~S}\right]$ methionine pulse-chased $\mathrm{VA}_{2} \mathrm{~B}$ cells or C4T cells with $\gamma$-globulins from an antiserum against the bovine $49 \mathrm{kDa}$ subunit, or from an antiserum against the human COII subunit, or from a normal rabbit serum (N.S.). The first two lanes show the patterns of samples of SDS mitochondrial lysates from pulse-chased $\mathrm{VA}_{2} \mathrm{~B}$ and $\mathrm{C} 4 \mathrm{~T}$ cells.

representing cytoplasmic proteins labeled during the chase (Chomyn et al., 1986). In the equivalent pattern from C4T cells, the labeled mtDNA-encoded subunits of Complex IV, Complex III and $\mathrm{H}^{+}$-ATPase were present in the same amounts as in the $\mathrm{VA}_{2} \mathrm{~B}$ pattern. By contrast, several of the mtDNA-encoded subunits of NADH dehydrogenase were apparently absent (ND4) or strongly reduced (ND2, ND6, ND3 and ND4L), with only ND1 being present in a normal amount. The ND5 subunit could not be clearly recognized due to the presence of closely migrating contaminating bands, but this subunit seemed to be present, though in reduced amount. In view of the previous finding that the rate of labeling of the mtDNA-encoded subunits of NADH dehydrogenase (with the exception of the ND4 subunit) is very similar in $\mathrm{VA}_{2} \mathrm{~B}$ and C4T cells (Figure 3 ), the above results clearly pointed to a marked difference in stability among the various Complex I subunits in C4T cells, presumably resulting from defective assembly.

Further evidence in favor of the lack of assembly of all or most of the mtDNA-encoded Complex I subunits came from experiments in which Triton X-100 mitochondrial lysates from $\mathrm{VA}_{2} \mathrm{~B}$ and $\mathrm{C} 4 \mathrm{~T}$ cells were incubated with $\gamma$-globulins from an antiserum against the purified bovine $49 \mathrm{kDa}$ iron-sulfur protein. As shown in Figure 5, the antibodies precipitated all the mtDNA-encoded subunits of Complex I from the $\mathrm{VA}_{2} \mathrm{~B}$ control lysate. By contrast, no clear evidence of such subunits, even those that were abundantly represented in the SDS mitochondrial lysate from
C4T cells (ND1 and ND2), could be seen in the immunoprecipitate from these cells (Figure 5). This failure of the mtDNA-encoded subunits to be precipitated as a complex is unlikely to be due to instability of this complex in the presence of Triton X-100, because the lack of assembly of these subunits has also been indicated by the results of the above described pulse-chase experiment. In a control experiment, antibodies against the $\mathrm{C}$-terminal undecapeptide of subunit II of human cytochrome $c$ oxidase (anti-COII) were able to precipitate the whole enzyme (Mariottini et al., 1986) from the mitochondrial lysates of both $\mathrm{VA}_{2} \mathrm{~B}$ and C4T (Figure 5). However, the bands corresponding to the three mtDNA-encoded subunits of the precipitated cytochrome $c$ oxidase appeared to be less intense in the case of C4T as compared with the $\mathrm{VA}_{2} \mathrm{~B}$ control. Since the labeling of these subunits was virtually identical in the SDS mitochondrial lysates from pulse - chased $\mathrm{VA}_{2} \mathrm{~B}$ and $\mathrm{C} 4 \mathrm{~T}$ cells, it is possible that the lower intensity of the bands in the immunoprecipitate from the C4T lysate is due to a secondary effect of the Complex I defect on the assembly of cytochrome $c$ oxidase in the transformant.

\section{Role of the ND4 subunit in Complex I}

The conclusion of the experiments described above was that all or most of the mtDNA-encoded subunits of Complex I are not assembled in the C4T transformant. That some of the nuclear-encoded subunits of Complex I are, on the contrary, still assembled in the transformant is suggested by the normal NADH: $\mathrm{Fe}(\mathrm{CN})_{6}$ oxidoreductase activity in the mutant mitochondria. It has been shown in Neurospora (Tuschen et al., 1990) that the two arms of the enzyme are assembled independently. If the same situation holds for human cells in culture, it has to be expected that the matrix arm of the enzyme is present in the inner mitochondrial membrane of the mutant.

The results reported here represent a clear-cut case of a drastic mutation in the mitochondrial genome that leads to a non-functional Complex I. Although we cannot absolutely exclude another mutation(s) in mtDNA gene(s) encoding subunits of NADH dehydrogenase, the presence of these subunits in normal amounts and with the expected electrophoretic mobilities in the protein labeling patterns obtained in the short and long pulse experiments makes the lack of the ND4 gene product the most plausible cause for the failure of the mtDNA-encoded subunits to assemble into Complex I.

There is strong evidence, coming both from biochemical experiments (Earley et al., 1987; Yagi and Hatefi, 1988; Friedrich et al., 1990) and from the study of the effects of mtDNA mutations in human diseases (Wallace, 1992), that at least some NADH dehydrogenase subunits play a role in the function of Complex I. For the ND4 gene, this evidence has come from studies on a mutation at position 11778 of the mitochondrial genome, which is associated with Leber's hereditary optic neuropathy (Wallace et al., 1988). Although this mutation leads to decreased Complex I activity, as determined by measurements of the rate of oxidation of NADH-linked substrates in isolated mitochondria from muscle or peripheral lymphocytes of patients carrying the mutation, a direct influence of the mutation on the electron transfer activity of Complex I could not be demonstrated (Larsson et al., 1991; Majander et al., 1991). The suggestion has therefore been made (Majander et al., 1991) 
that the ND4 subunit may be involved in forming a domain in Complex I necessary for the association of NADH-linked dehydrogenases with this enzyme complex, which would facilitate the NADH transfer between them. Indeed many of these dehydrogenases have been shown to be associated with Complex I, with possible important kinetic implications (Sumegi and Srere, 1984). On the other hand, the lack of enzyme activity observed in the mutant $\mathrm{C} 4$ implies a more essential role of the ND4 subunit than just that of facilitating substrate channeling. In fact, the present observation suggest that the ND4 subunit is important for the assembly of the membrane arm of Complex I or the association between the membrane and the matrix arm of the enzyme; therefore, these results would place some structural constraints on any model involving an additional role for this subunit in promoting substrate transfer to the matrix arm. Whether the ND4 subunit is involved in electron transfer or in proton translocation remains to be investigated.

\section{Materials and methods}

\section{Cell lines and media}

The human cell line $\mathrm{VA}_{2} \mathrm{~B}$ (Mitchell et al., 1975) was grown in Dulbecco's modified Eagle's medium (DMEM) supplemented with $10 \%$ calf serum and $3 \mu \mathrm{g} / \mathrm{ml} 8$-azaguanine. The rotenone-resistant clone $\mathrm{C} 4$ was grown in the above medium supplemented with $1 \mu \mathrm{M}$ rotenone. The $\varrho^{\circ} 206$ cell line (King and Attardi, 1989), a derivative of 143B.TK ${ }^{-}$cells, was grown in DMEM supplemented with $5 \%$ fetal bovine serum (FBS), $50 \mu \mathrm{g}$ uridine per $\mathrm{ml}$ and $100 \mu \mathrm{g}$ 5-bromodeoxyuridine (BrDU) per $\mathrm{ml}$.

\section{Mitochondria-mediated transformation}

$\varrho^{\circ}$ cell transformation by cytoplast fusion was carried out as previously described (King and Attardi, 1989). Transformant C4T was isolated in DMEM supplemented with 5\% dialyzed FBS and $100 \mu \mathrm{g}$ of BrdU per ml.

\section{$\mathrm{O}_{2}$ consumption by digitonin-permeabilized cells}

Cells were grown in rotenone-free medium for $24 \mathrm{~h}$ prior to the measurement. About $10^{7}$ cells were harvested by trypsinization, resuspended in $1 \mathrm{ml}$ of buffer (20 mM HEPES, pH 7.1, $10 \mathrm{mM} \mathrm{MgCl}, 250 \mathrm{mM}$ sucrose), and then $100-150 \mu \mathrm{g}$ digitonin $(1-1.5 \mu \mathrm{l}$ of a $10 \%$ solution in DMSO) were added while mixing; after addition of $9 \mathrm{ml}$ of buffer, the cells were pelleted and resuspended in $\sim 100 \mu \mathrm{l}$ of buffer. After introduction of the cells into the chamber of a Gilson 5/6 Oxygraph, this was filled up with $1.8 \mathrm{ml}$ of respiration medium (20 mM HEPES, pH 7.1, $2 \mathrm{mM} \mathrm{KP}$, $10 \mathrm{mM} \mathrm{MgCl}_{2}$ and $1.0 \mathrm{mM} \mathrm{ADP}$ ), and then two small aliquots were removed to determine the exact number of cells in the chamber. Substrates and inhibitors were added with Hamilton syringes from $200 \times$ stock solutions (neutralized with $\mathrm{NaOH}$ when necessary). Final concentrations were: malic acid, $5 \mathrm{mM}$; glutamic acid, $5 \mathrm{mM}$; succinic acid, $5 \mathrm{mM}$; $\mathrm{Na}_{2}$ glycerol-3-phosphate, 5 $\mathrm{mM}$; ascorbic acid, $5 \mathrm{mM}$; TMPD, $0.2 \mathrm{mM}$; rotenone, $100 \mathrm{nM}$; antimycin, $4 \mathrm{nM} ; \mathrm{KCN}, 1 \mathrm{mM}$.

\section{Enzymatic tests}

The mitochondrial fraction was isolated from $\sim 0.5 \mathrm{ml}$ of packed cells as described elsewhere (Storrie and Attardi, 1972), resuspended in $8 \mathrm{ml} 20 \mathrm{mM}$ Tris, $\mathrm{pH} 7.5$, at $4^{\circ} \mathrm{C}$, and sonicated for $40 \mathrm{~s}$ in four $10 \mathrm{~s}$ pulses separated by $15 \mathrm{~s}$ intervals. Mitochondrial membranes were pelleted by centrifugation at 39000 r.p.m. in a Beckman Ty 65 fixed angle rotor for $60 \mathrm{~min}$ and resuspended in the buffer mentioned above at a protein concentration (determined by the Bio-Rad assay) of $\sim 15 \mathrm{mg} / \mathrm{ml}$. The activities were measured, at a protein concentration of $160 \mu \mathrm{g} / \mathrm{ml}$ for the $\mathrm{Q}_{1}$ reduction and $30 \mu \mathrm{g} / \mathrm{ml}$ for the $\mathrm{Fe}(\mathrm{CN})_{6}$ reduction, in $20 \mathrm{mM}$ Tris, $\mathrm{pH} 7.5,1 \mathrm{mM} \mathrm{KCN}$ $100 \mu \mathrm{M} \mathrm{NADH}$ and $50 \mu \mathrm{M} \mathrm{Q} \mathrm{Q}_{1}$ (Esai Co., Japan) or $1 \mathrm{mM} \mathrm{Fe}(\mathrm{CN})_{6}$. The reaction was monitored at $275 \mathrm{~nm}$ for the reduction of $\mathrm{Q}_{1}(\epsilon=12250)$ and at $410 \mathrm{~nm}$ for the reduction of $\mathrm{Fe}(\mathrm{CN})_{6}(\epsilon=1.0)$. The NADH: $\mathrm{Q}_{1}$ oxidoreductase activity of the $\mathrm{VA}_{2} \mathrm{~B}$ control was reduced by $97 \%$ by $100 \mathrm{nM}$ rotenone.

\section{Mitochondrial protein synthesis analysis}

Labeling was performed according to Chomyn et al. (1991). Samples of $10^{6} \mathrm{VA}_{2} \mathrm{~B}$ or $\mathrm{C} 4 \mathrm{~T}$ cells were plated on $5 \mathrm{~cm}$ dishes and grown overnight. After washing the cells with methionine-free DMEM, $5 \mathrm{ml}$ of the same medium containing $100 \mu \mathrm{g} / \mathrm{ml}$ emetine were added to each plate. After 10 min incubation, $\left.{ }^{35} \mathrm{~S}\right]$ methionine was added $(0.1 \mathrm{mCi}$ for the $2 \mathrm{~h}$ pulse, $0.5 \mathrm{mCi}$ for the 20 and $40 \mathrm{~min}$ pulses) and the plates were incubated for the times indicated in the figure. The cells were then trypsinized, washed and lysed in $1 \%$ SDS. Samples containing $75 \mu \mathrm{g}$ protein were electrophoresed through an SDS-polyacrylamide (15-20\% exponential) gel.

\section{DNA sequencing}

The segment of the C4T and $\mathrm{VA}_{2} \mathrm{~B}$ mtDNAs between positions 10420 and 12161 , which contains the ND4L and the ND4 genes, was amplified by PCR with appropriate oligonucleotides in two overlapping portions of 989 and $896 \mathrm{bp}$ in length. The PCR products were electrophoresed on an agarose gel in Tris-acetate-EDTA, eluted from the gel and ethanolprecipitated; the purified double-stranded fragments were directly sequenced by the chain termination method (Sanger et al., 1977) using the CircumVent DNA polymerase (NEB) and $\left[{ }^{35} \mathrm{~S}\right] \mathrm{ATP}$. The products of the sequencing reactions were separated on a $0.4 \mathrm{~mm} 6 \%$ polyacrylamide-urea gel.

\section{Immunoprecipitation experiments}

As described by Chomyn et al. (1985), samples of $3 \times 10^{6}$ cells were plated on $10 \mathrm{~cm}$ dishes, grown for $22 \mathrm{~h}$ in the presence of $40 \mu \mathrm{g} / \mathrm{ml}$ chloramphenicol (CAP) to accumulate nuclear-encoded subunits of Complex I, washed with methionine-free DMEM to remove CAP and methionine, incubated for $10 \mathrm{~min}$ in the same medium with $100 \mu \mathrm{g} / \mathrm{ml}$ cycloheximide (CHX), and then exposed for $2 \mathrm{~h}$ to $1 \mathrm{mCi}\left[{ }^{35}\right.$ S]methionine. Thereafter, the CHX was washed away, and the cells were subjected to a $16 \mathrm{~h}$ chase in complete unlabeled medium to allow the incorporation of the labeled mtDNA-encoded subunits into Complex I. The cells were trypsinized and washed, and the mitochondrial fraction was isolated and lysed in $0.5 \%$ Triton Samples containing $120 \mu \mathrm{g}$ protein were incubated at $4^{\circ} \mathrm{C}$ with $72 \mu \mathrm{g}$ of $\gamma$-globulins from either an antiserum against the bovine $49 \mathrm{kDa}$ subunit (Chomyn et al., 1986), or an anti-COII antiserum (Mariottini et al., 1986), or a normal rabbit serum. Immunocomplexes were bound to formaldehydefixed Staphylococcus aureus (Zysorbin, Seemed) (Chomyn et al., 1985), spun down and washed several times. The final pellets were dissolved in $1 \%$ SDS and separated on an SDS-polyacrylamide (15-20\% exponential) gel.

\section{Acknowledgements}

These investigations were supported by NIH grant GM-11726 to G.A. and by a Fellowship from the Deutsche Forschungsgemeinschaft to G.H. We thank Anne Chomyn for help in the immunoprecipitation experiments, and Ms Benneta Keeley and Ms Lisa Tefo for technical assistance.

\section{References}

Anderson,S. et al. (1981) Nature, 290, 457-465.

Chomyn,A., Mariottini,P., Cleeter,M.W.J., Ragan,C.I., Matsuno-Yagi,A., Hatefi,Y., Doolittle,R.F. and Attardi,G. (1985) Nature, 314, 592-597.

Chomyn,A., Cleeter,M.W.J., Ragan,C.I., Riley,M., Doolittle,R.F. and Attardi,G. (1986) Science, 234, 614-618.

Chomyn,A., Meola,G., Bresolin,N., Lai,S.T., Scarlato,G. and Attardi,G. (1991) Mol. Cell. Biol., 11, 2236-2244.

Earley,F.G., Patel,S.D., Ragan,C.I. and Attardi,G. (1987) FEBS Lett., 219, 108-113.

Friedrich,T., Strohdeicher,M., Hofhaus,G., Preis,D., Sahm,H. and Weiss,H. (1990) FEBS Lett., 265, 37-40.

Galante,Y. and Hatefi,Y. (1979) Arch. Biochem. Biophys., 192, 559-568. Granger,L.D. and Lehninger,A.L. (1982) J. Cell Biol., 95, 527-535.

Hofhaus,G., Weiss,H. and Leonard,K. (1991) J. Mol. Biol., 221, 1027-1043.

King,M.P. and Attardi,G. (1989) Science, 246, 500-503.

Larsson,N.-G., Anderson,O., Holme,E., Oldfors,A. and Wahlström,J. (1991) Ann. Neurol., 301, 133-140.

Majander,A., Huoponen,K., Savontaus,M.1., Nikoskelainen,E. and Wikstrom,M, (1991) FEBS Lett., 292, 289-292.

Mariottini,P., Chomyn,A., Doolittle,R.F. and Attardi,G. (1986) J. Biol. Chem., 261, 3355-3362.

Mitchell,C.H., England,J.M. and Attardi,G. (1975) Somat. Cell Genet. 1, 215-237.

Sanger,F., Nicklen,S. and Coulson,A.R. (1977) Proc. Natl Acad. Sci. USA, 74, $5463-5467$

Storrie,B. and Attardi,G. (1972) J. Mol. Biol., 71, 931-937.

Sumegi,B. and Srere,P.A. (1984) J. Biol. Chem., 259, 15040-15045. 
Tuschen,G., Sackmann,U., Nehls,U., Haiker,H., Buse,G. and Weiss,H. (1990) J. Mol. Biol., 213, 845-857.

Walker,J. E. (1992) Q. Rev. Biophys., 25, 253-324.

Wallace,D.C. (1992) Annu. Rev. Biochem., 61, 1175-1212.

Wallace,D.C., Singh,G., Lott,M.T., Hodge,J.A., Schwir,T.G., Lezza,A.M.S. and Elsas,L.T. (1988) Science, 242, 1427-1430.

Weiss,H., Friedrich,T., Hofhaus,G. and Preis,D. (1991) Eur. J. Biochem., 197, 563-576.

Yagi,T. and Hatefi,Y. (1988) J. Biol. Chem., 263, 16150-16155.

Received on February 4, 1993; revised on April 20, 1993 